\title{
Gas Chromatography in the Analysis of Compounds Released from Wood into Wine
}

\author{
Maria João B. Cabrita ${ }^{1}$, Raquel Garcia ${ }^{1}$, Nuno Martins' ${ }^{1}$, \\ Marco D.R. Gomes da Silva ${ }^{2}$ and Ana M. Costa Freitas ${ }^{1}$ \\ ${ }^{1}$ School of Science and Technology, Department of Plant Science, Institute of Agricultural \\ and Environmental Science ICAAM Mediterranean, University of Évora, Évora, \\ ${ }^{2}$ REQUIMTE, Department of Chemistry, Faculty of Science and Technology, \\ New University of Lisbon, Campus Caparica, \\ Portugal
}

\section{Introduction}

Wood has been used in alcoholic beverages for centuries, mainly as material for containers used for alcoholic beverages aging. Recently OIV (Organisation International de la Vigne et $\mathrm{du}$ Vin) approved the use of chips (Resolution oeno 3/2005) and staves as alternatives for barrels. These practices are being rapidly spread among winemakers. The increased used of these alternatives are mainly related to low investments, similar sensorial results obtained in shorter time, simplicity of use and the possibility of avoiding contamination and offflavours, too-often related to aged or contaminated barrels.

Besides oak, other woods are being looked at for enological purposes, such as acacia, cherry, chestnut and mulberry. Their characteristics are commonly compared to oak. In the past, chestnut (Castanea sativa) was widely used in the Mediterranean area, because of its availability and its cheap price. Chestnut wood has higher porosity than oak. Cherry wood (Prunus avium) has high porosity and oxygen permeation, and is usually used for short aging times. Acacia wood (Robinia pseudoacacia) is hard, with low porosity. Mulberry wood (Morus alba and Morus nigra) is tender and elastic, with medium porosity, and is characterized by a low release of compounds. The lack of properties for cooperage is now overcome by their possible use as staves or chips.

The aim of this work is to present an overview on volatile and semi-volatile composition of different kind of wood with oenological interest. Within this purpose, this work will be focused on a bibliographic review of the most used chromatographic methods for characterization of volatile and semi-volatile compounds, including also a brief description of the most common reported sample preparation methods for chromatographic analysis.

The composition of woods volatile fraction depends on the botanical species and geographic origin. Prior to its final use a toasting step is needed. This toasting process induces the formation of a great number of volatile and odoriferous compounds, and it is the main reason for significant differences among non-toasted and toasted wood. Volatiles and semi- 
volatiles compounds from wood belong to several different chemical families: lactones, terpenes, norisoprenoids, aldehydes, ketones, alcohols, phenols and esters.

Because of the odourific impact of some volatiles, a number of studies dealt with their characterization in wood-aged beverages and woods itself. Volatile phenols such as guaiacol and eugenol, phenolic aldehydes such as vanillin and syringaldehyde, oak lactones, and furanic aldehydes (furfural and derivatives) have been described as the main contributors to the sensory fingerprinting of aged alcoholic beverages.

Most of the volatile compounds are formed during open-air seasoning and toasting phases of wood processing. Several furanic aldehydes and ketones come from the thermo degradation of celluloses and hemicelluloses. This is the case of hydroxy-methylfurfural (HMF) (from cellulose-derived glucose) and furfural arising from pentoses produced by partial hydrolysis of hemicelluloses. These latter compounds are responsible for almond and toasty odours. Thermal degradation of lignin determines the formation of methoxylated volatile phenols (i.e., guaiacyl and syringyl derivatives), phenolic ketones, and phenolic aldehydes contributing to smoked or spiced and vanilla aromas, respectively.

To study volatiles in woods or in alcoholic beverages some preparation methods must be considered. The volatile fraction from woods can be studied from three different points of view: the volatiles existing in wood itself, the volatiles that wood can release into synthetic medium miming alcoholic beverages and the study of alcoholic beverages like wines and spirits after aging with wood contact. In practical terms, that implies using sample preparation methods for solid and liquid matrices.

Sample preparation for gas chromatography (GC) analysis of volatile compounds from woods can be performed by pressurized liquid extraction, a process that combines temperature and pressure with liquid solvent to achieve extracts rapidly and efficiently. This technique is available in an automated or a manual version as accelerated solvent extraction (ASE), and it is being currently used as a good alternative for the solid-liquid extraction used previously for studying volatiles from solid matrices. Most of the "oldest" sample preparation methods involved Soxhlet extraction with dichloromethane or methanol or simultaneous distillation-extraction procedures.

The sample preparation procedures for GC analysis of volatile compounds in wines or hydro-alcoholic mixtures in general, are usually done by LLE (liquid-liquid extraction), SPE (solid-phase extraction) or SPME (solid-phase microextraction). But, more environmental friendly sample preparation techniques like SBSE (stir bar sorptive extraction) can also be employed with good results when thermal desorption is used instead of retro-extraction, for subsequent chromatographic analysis.

The chromatographic technique more suitable for these analyses is gas chromatographymass spectrometry (GC/MS), as the mass spectrometer allows a more powerful tool for compounds identification. When MS is coupled with two-dimensional (2D) chromatographic systems, broader capabilities can be open in order to fully characterized wine matrices. An olfactometric approach is also mandatory in order to identify chromatogram zones where peak identification should take place. Consequently gas chromatography-olfactometry (GC-O) emerges as an important technique to achieve this purpose. GC-O analysis has been widely used to identify odour-active compounds or to 
screen the odour volatile composition in wines. This technique allows to obtain relatively simple olfactograms and to establish a hierarchy of the most important odorants according to their potential sensory impact. In general it implies the use of headspace technique as sample preparation method, such as purge-and-trap (P\&T) or solid-phase microextraction (HS-SPME) systems.

\section{Composition and biosynthesis of the volatile fraction of woods: Effect of botanical species and toasting}

For centuries, wood has been used in wine technology, either as containers for transportation either for aging wine and spirits. Over the years, many different tree species have been used in cooperage, but oak and chestnut woods proved to be the best ones to manufacture barrels and therefore the most suitable ones for wine and spirits aging.

The use of barrels is, however, expensive since barrels can only be used few times for wine aging. Besides the above mentioned issue, barrels can often be the cause of wine contaminations and off-flavours, if sanitation procedures are not correctly applied.

All woods are composed of cellulose, lignin, ash-forming minerals, and extractives formed into a cellular structure. The characteristics and amounts of these compounds and differences in cellular structures give to each wood its specific characteristics. Some are more flexible than others, some are easier to work, some are harder or softer, heavier or lighter.

Extractives from different wood species comprise several substances which belong to an extremely wide range of chemical families that are characteristics of each wood. Thus, extractives allow the identification of wood species, contributing also for the determination of other wood properties, namely permeability, density, hardness and compressibility.

Besides botanical species, geographical origin also contributes to the final chemical composition of the extractives. Technological treatments during cooperage such as seasoning and toasting give the final characteristics to the barrel (Chatonnet \& Dubourdieu, 1998; Cadahía et al., 2001; Doussot et al., 2002; Pérez-Prieto et al., 2002; Cadahía et al., 2003).

Wood physical properties play a significant role in cooperage. Usually, oak is the most used specie due to its unique physical and chemical nature. Physically, oak has strength since its wide radial rays give strength when shaped for a cask. Oak is also a "pure wood" as opposed to pine or rubber trees which contain resin canals that can transfer strong flavours to maturing beverages.

Several studies have been conducted in order to evaluate the accumulation of oak volatile compounds in wines and spirits and how different factors affect the final concentration of these compounds both in barrels (Puech, 1987; Sefton et al., 1993; Yokotsuka et al., 1994; Waterhouse \& Towey, 1994; Piggot et al., 1995; Escalona et al., 2002; Ferreras et al., 2002; Pérez-Prieto et al., 2002, 2003; Netto et al., 2003; Madrera et al., 2003; Garde-Cerdán et al., 2002, 2004; Gómez-Plaza et al., 2004; Jarauta et al., 2005; Garde Cerdán \& Ancín-Azpilicueta, 2006 b; Caldeira et al., 2006 a,b; Jiménez-Moreno \& Ancín-Azpilicueta, 2007; JiménezMoreno et al., 2007; Frangipane et al., 2007) and with oak chips (Pérez-Coello et al., 2000; Arapitsas et al., 2004; Caldeira et al., 2004; Guchu et al., 2006; Frangipane et al., 2007; Bautista-Ortin et al., 2008; Rodríguez-Bencomo et al., 2008, 2009; Rodríguez- Rodríguez \& Gómez-Plaza, 2011). 
Other studies were made in model solutions to avoid matrix influence (Singleton \& Draper, 1961; Ancín-Azpilicueta et al., 2004; Fernández de Simón et al., 2010 a; RodríguezRodríguez \& Gómez-Plaza, 2011) or in wood itself (Vichi et al., 2007; Natali et al., 2006; DíazMaroto et al., 2008).

More recently some studies have been made with other woods than oak (Flamini, et al., 2007; de Rosso et al., 2009; Fernández de Simón et al., 2009; Caldeira et al., 2010) as they becoming increaseling interesting.

Ever since OIV approved the use of alternatives for barrels, like chips and staves, researchers are looking into other kind of woods such as acacia, cherry and mulberry, which were abandoned in the past due to the lack of cooperage properties.

\subsection{Effect of botanical species}

The main botanical species used in cooperage is oak (genus Quercus) and in a lesser extension, chestnut (genus Castanea). The oak species more used in cooperage are Quercus alba (American oak) growing in different areas of the United States, Quercus patraea Liebl. (sessili oak), Quercus Robur L. (pedunculate oak) and Quercus pyrenaica growing in Europe. French oaks are the most widespread wood for barrels, especially those from Allier and Limousin regions. But oaks from Hungary, Russia, Spain, Romania and Portugal are also becoming more and more attractive.

Many researchers are now dedicated to the study of chemical compounds in different kind of woods, although oak is still the most studied one. Whenever a new wood is tested it is compared with the oak effects in wines and spirits. Oak belonging to different species can be significantly different regarding volatile composition. Jordão et al. (2006) concluded that Quercus pyrenaica released significantly more volatile compounds than Quercus patraea, in a study with SPME in hydro-alcoholic oak wood solutions. Fernández de Simón et al., (2010 a) concluded that Quercus pyrenaica chips, althought similar to other species, have some odourific particularities, such as high levels of furanic compounds, eugenol, furaneol and cis-whiskylactone and low levels of vanillin. Several authors pointed out that $\beta$-methyl- $\gamma-$ octalactone (whisky lactone), particularly the cis isomer, can be used to differentiate American from French oaks (Masson et al., 1995; Waterhouse \& Towey, 1994; Masson et al., 1997; Chatonnet \& Dubourdieu, 1998; Pérez-Coello et al, 1999). Several norisoprenoid compounds were found in American oak, but were almost absent in European oaks (Sefton et al., 1990). Same wood species from French oak and East European oaks can be distinguished by their contents of eugenol, 2-phenylethanol and aromatic aldehydes, mostly vanillin and syringaldehyde (Prida \& Puech 2006).

The chemical compounds released from acacia, chestnut, cherry, mulberry and oak untoasted woods into alcoholic extracts, shows that each wood has a different and characteristic profile (Flamini et al., 2007, de Rosso et al., 2009, Fernández de Simon et al., 2009). Acacia had significant aromatic aldehydes, particularly vanillin, syringaldehyde and dihydroxy-benzaldehyde but no eugenol (de Rosso et al., 2009) or methoxyeugenol (Flamini et al., 2007) were found. Chestnut and oak showed the highest content of volatile compounds namely vanillin, eugenol, methoxyeugenol, syringaldehyde, $\alpha$-terpineol, and oak presented high amouts of cis- and trans- $\beta$-methyl- $\gamma$-octalactones. In cherry, several 
aromatic compounds were found although in low abundance, but mulberry was the poorest, with small amounts of eugenol and absence of methoxyeugenol (de Rosso et al., 2009). Cherry is also characterized by methoxyphenols, particularly, high content of trimethoxyphenol (Flamini et al., 2007). Chestnut and oak woods are known to release significant amounts of eugenol and methoxyeugenol into wines. High amounts of vanillin are released from chestnut and high levels of syringaldehyde are released from acacia and oak woods.

\subsection{Effect of toasting level}

Oak wood chemical composition mainly depends on the species, its provenience and the various treatments that wood undergoes in cooperage, such as seasoning, region of seasoning and toasting (Marco et al., 1994; Chatonnet \& Dubourdieu, 1998; Cadahía et al., 2001; Doussot et al., 2002; Pérez-Prieto et al., 2002; Cadahía et al., 2003).

Seasoning prevents the wood from shrinking after barrel production while firing is applied to stabilise the curved shape of the barrel (van Jaarsveld et al., 2009) and both these steps play a crucial role in wood flavour development.

Wood seasoning in cooperage is usually performed under natural conditions in open air during a variable period of time (18 to 36 months), but artificial seasoning can also be performed. However, natural seasoning has a more positive effect on the odourific profile of wood. During this process the wood volatile compounds profiles, which include lactones, phenolic aldehydes or volatile phenols, show significant differences.

Nevertheless, among all variables that can influence the impact of woods in wine or spirits sensory changes, heating is the most important. Toasting has a significant influence on wood's chemical compounds, modifying both, the quantity and the quality of the extractable substances (Cutzach et al., 1997; Chatonnet et al., 1999). The toasting process drastically enhances the gain in volatile compounds arising from the thermal degradation of oak wood (Cutzach et al., 1997; Chatonnet et al., 1999; Doussot et al., 2002).

When heat is applied to wood during toasting process, chemical bonds are disrupted within biopolymers such as cellulose, hemicellulose, lignin, polysaccharides, polyphenols and lipids, resulting in degradation or compositional changes by pyrolysis and thermolysis (Fernández de Simón et al., 2009; van Jaarsveld et al., 2009), which induce a notable modification of wood chemical composition.

Volatile phenols, phenolic aldehydes, phenyl ketones and some phenyl alcohols are mainly formed from lignin thermodegradation. In particular, high levels of mono and dimethoxylated phenols, benzoic and cinnamic aldehydes were identified in toasted wood.

Heat degradation of polyosides leads to the production of furanic aldehydes, pentacyclic and hexacyclic ketones. Lactones, formed from wood lipids, increase their concentration at the beginning of toasting, although they can be destroyed by a lengthy toasting process (Giménez-Martínez et al., 1996; Chatonnet et al., 1999; Cadahía et al., 2003). This thermo degradation process leads to the formation of several compounds that can be transferred to wine and spirits during aging or maturation, hence, extensive information about the volatile 
composition of wood used in cooperage would be of great interest to the wine industry. Table 1 resumes information regarding main volatile compounds formed from wood biopolymer during toasting process.

\begin{tabular}{|c|c|c|c|c|c|}
\hline Common name & IUPAC name & $\begin{array}{l}\mathrm{m} / \mathrm{z} \\
\text { fragment }\end{array}$ & $\begin{array}{l}\text { LRI } \\
\text { Apolar } \\
\text { column }\end{array}$ & \begin{tabular}{|l|} 
LRI \\
Polar \\
column
\end{tabular} & Aroma notes \\
\hline \multicolumn{6}{|c|}{ DERIVED FROM POLYSACHARIDES } \\
\hline \multicolumn{6}{|l|}{ Furanic aldeydes } \\
\hline Furfural & 2-Furancarboxaldehyde & 95,96 & $\begin{array}{l}834^{(\mathrm{a})} \\
811^{(\mathrm{h})}\end{array}$ & $1444^{(b)}$ & $\begin{array}{l}\text { Bread, sweet } \\
\text { almond (i), } \\
\text { slightly toasty, } \\
\text { caramel(h) }\end{array}$ \\
\hline 5-Methylfurfural & $\begin{array}{l}\text { 5-Methyl-2- } \\
\text { furancarboxaldehyde }\end{array}$ & $109, \mathbf{1 1 0}$ & 965(a) & $1551^{(\mathrm{b})}$ & $\begin{array}{l}\text { Almond, } \\
\text { caramel(i), } \\
\text { spicy, toasty }{ }^{(h)}\end{array}$ \\
\hline \begin{tabular}{|l} 
5-Hydroxy \\
methylfurfural
\end{tabular} & $\begin{array}{l}\text { 5-Hydroxymethyl-2- } \\
\text { furancarboxaldehyde }\end{array}$ & 97,126 & 1235 (a) & $2466^{(b)}$ & Odourless(n) \\
\hline Maltol & $\begin{array}{l}\text { 3-Hydroxy-2-methyl-4H- } \\
\text { pyran-4-one }\end{array}$ & 71,126 & 1111 (a) & $1938(b)$ & Toasty(n) \\
\hline Furaneol & $\begin{array}{l}\text { 4-Hydroxy-2,5-dimethyl- } \\
3(2 \mathrm{H}) \text {-furanone }\end{array}$ & $85, \mathbf{1 2 8}$ & 1083(a) & $2013(\mathrm{~b})$ & Caramel-like(o) \\
\hline \multicolumn{6}{|l|}{ Acids } \\
\hline Acetic acid & Ethanoic acid & $43,45,60$ & 602(g) & $1464^{(\mathrm{f})}$ & vinegar $(\mathrm{f})$ \\
\hline \multicolumn{6}{|c|}{ DERIVED FROM LIGNIN AND POLYPHENOLS } \\
\hline \multicolumn{6}{|l|}{ Volatile phenols } \\
\hline Eugenol & $\begin{array}{l}\text { 2-Methoxy-4-(prop-2- } \\
\text { enyl) phenol }\end{array}$ & $\begin{array}{l}77,103 \\
164\end{array}$ & 1359(a) & 2139 (b) & $\begin{array}{l}\text { Clove,honey (i) } \\
\text { spicy, } \\
\text { cinnamon }(\mathrm{h})\end{array}$ \\
\hline $\begin{array}{l}\text { Isoeugenol (cis and } \\
\text { trans) }\end{array}$ & $\begin{array}{l}\text { cis- and trans-1- } \\
\text { Methoxy-4- } \\
\text { (prop-2-enyl) phenol }\end{array}$ & $\begin{array}{l}77,149, \\
\mathbf{1 6 4}\end{array}$ & $\begin{array}{l}1408^{(\mathrm{a})} \\
1451^{\text {(a) }}\end{array}$ & $\begin{array}{l}2226^{(b)} \\
2314^{(b)}\end{array}$ & $\begin{array}{l}\text { Spicy }(\mathrm{m}) \\
\text { clove, woody }(\mathrm{h})\end{array}$ \\
\hline Phenol & Hydroxybenzene & 66,94 & 983(a) & $1978^{(b)}$ & $\operatorname{Ink}(\mathrm{n})$ \\
\hline \begin{tabular}{|l|}
$3,4-$ \\
Dimethylphenol \\
\end{tabular} & $\begin{array}{l}\text { 1-Hydroxy-3,4- } \\
\text { dimethylbenzene }\end{array}$ & 107 & $1193^{(a)}$ & $2192^{(b)}$ & \\
\hline$o$-Cresol & 2-Methylphenol & $107 / 108$ & 1059(a) & 1980(b) & Leather, spicy(m) \\
\hline$p$-Cresol & 4-Methylphenol & $107 / 108$ & 1079(a) & $2056^{(\mathrm{b})}$ & \\
\hline$m$-Cresol & 3-Methylphenol & $107 / 108$ & $1086^{(\mathrm{a})}$ & $2064^{(b)}$ & \\
\hline Guaiacol & 2-Methoxyphenol & $109 / 124$ & 1089(a) & $1833^{(b)}$ & $\begin{array}{l}\text { Smoke,sweet, } \\
\text { medicine (i) }\end{array}$ \\
\hline 4-Methylguaiacol & \begin{tabular}{|l|} 
4-Methyl-2- \\
methoxyphenol
\end{tabular} & $123 / 138$ & $1191^{(\mathrm{a})}$ & $1928^{(b)}$ & $\begin{array}{l}\text { Spicy,phenolic, } \\
\text { lightly green }(\mathrm{h})\end{array}$ \\
\hline 4-Ethylguaiacol & $\begin{array}{l}\text { 4-Ethyl-2- } \\
\text { methoxyphenol }\end{array}$ & $137 / 152$ & 1274 (a) & $2002^{(b)}$ & $\begin{array}{l}\text { Phenolic }(\mathrm{i}, \mathrm{m}) \\
\text { leather(m) } \\
\text { smoked }^{(\mathrm{i})}\end{array}$ \\
\hline 4-Propylguaiacol & $\begin{array}{l}\text { 4-Propyl-2- } \\
\text { methoxyphenol }\end{array}$ & $137 / 166$ & $1461^{(\mathrm{a})}$ & $2083^{(b)}$ & $\begin{array}{l}\text { Leather } \\
\text { animal }(\mathrm{m})\end{array}$ \\
\hline
\end{tabular}




\begin{tabular}{|c|c|c|c|c|c|}
\hline Common name & IUPAC name & \begin{tabular}{|l|}
$\mathrm{m} / \mathrm{z}$ \\
fragment
\end{tabular} & $\begin{array}{l}\text { LRI } \\
\text { Apolar } \\
\text { column }\end{array}$ & \begin{tabular}{|l|} 
LRI \\
Polar \\
column
\end{tabular} & Aroma notes \\
\hline 4-Vinylguaiacol & $\begin{array}{l}\text { 4-Vinyl- } \\
\text { 2-metoxyphenol }\end{array}$ & $135 / 150$ & $1314^{(\mathrm{a})}$ & $2165^{(b)}$ & Clove ${ }^{(i)}$ \\
\hline Syringol & 2,6-Dimethoxyphenol & $139 / 154$ & 1353(a) & $2237(\mathrm{~b})$ & $\begin{array}{l}\text { Smoke, burned } \\
\operatorname{wood}(\mathrm{f})\end{array}$ \\
\hline 4-Methylsyringol & $\begin{array}{l}\text { 4-Methyl-2,6- } \\
\text { dimetoxyphenol }\end{array}$ & 168 & 1449 (a) & $2322^{(b)}$ & $\begin{array}{l}\text { Smoke,burned, } \\
\text { flowery }{ }^{(f)}\end{array}$ \\
\hline 4-Ethylsyringol & $\begin{array}{l}\text { 4-Ethyl-2,6- } \\
\text { dimethoxyphenol }\end{array}$ & 167 & 1528 (a) & $2381^{(b)}$ & \\
\hline 4-Allylsyringol & $\begin{array}{l}\text { 4-Allyl-2,6- } \\
\text { dimethoxyphenol }\end{array}$ & 194 & 1605 (a) & $2511^{(b)}$ & Spicy smoky(m) \\
\hline 4-Propylsyringol & $\begin{array}{l}\text { 4-Propyl-2,6- } \\
\text { dimethoxyphenol }\end{array}$ & 167 & $1612^{\text {(a) }}$ & $2452^{(b)}$ & \\
\hline 4-Ethylphenol & $\begin{array}{l}\text { 1-Ethyl-4- } \\
\text { hydroxybenzene }\end{array}$ & 107,122 & & $2201^{(\mathrm{f})}$ & $\begin{array}{l}\text { Animal, } \\
\text { horse, stable }(\mathrm{f})\end{array}$ \\
\hline 2-Phenylethanol & Hydroxyethylbenzene & 91 & $1113^{(\mathrm{a})}$ & $1888^{(b)}$ & $\begin{array}{l}\text { Floral, } \\
\text { roses }(\mathrm{h})\end{array}$ \\
\hline \multicolumn{6}{|l|}{ Phenolic aldeydes } \\
\hline Vanillin & $\begin{array}{l}\text { 4-Hydroxy-3- } \\
\text { methoxybenzaldehyde }\end{array}$ & $151 / 152$ & 1399(a) & $2518^{(b)}$ & Vanilla (i) \\
\hline Benzaldehyde & Phenylmethanal & 77,106 & 962(a) & $1493^{(b)}$ & $\begin{array}{l}\text { Bitter almonds } \\
\text { (h) }\end{array}$ \\
\hline Conyferaldehyde & $\begin{array}{l}\text { 3-Methoxy-4- } \\
\text { hydroxycinnamaldehyde }\end{array}$ & 178 & 1747 (a) & $3096^{(b)}$ & $\begin{array}{l}\text { Vanilla, } \\
\text { woody(n) }\end{array}$ \\
\hline Syringaldehyde & \begin{tabular}{|l|} 
4-Hydroxy-3,5- \\
dimethoxybenzaldehyde
\end{tabular} & 181,182 & 1643 (a) & $2904^{(b)}$ & Vanilla (i) \\
\hline Sinapaldehyde & $\begin{array}{l}\text { 3,5-Dimethoxy-4- } \\
\text { hydroxycinnamaldehyde }\end{array}$ & 208 & $2002^{\text {(a) }}$ & $3458^{(b)}$ & $\operatorname{Vanilla}^{(\mathrm{n})}$ \\
\hline \multicolumn{6}{|l|}{ Phenolic esters } \\
\hline Ethyl vanillate & $\begin{array}{l}\text { 4-Hydroxy-3-methoxy } \\
\text { benzoic acid, } \\
\text { ethyl ester }\end{array}$ & $\begin{array}{l}151 \\
167,196\end{array}$ & $1648(\mathrm{~g})$ & & \begin{tabular}{|l} 
Flower, \\
vanilla,fruit, \\
sweet, (i) \\
\end{tabular} \\
\hline Methyl vanillate & $\begin{array}{l}\text { 4-Hydroxy-3-methoxy } \\
\text { benzoic acid, } \\
\text { methyl ester }\end{array}$ & 151,182 & 1518 (a) & 2565 (b) & $\begin{array}{l}\text { Caramel, } \\
\text { butterscotch, } \\
\text { vanilla (i) }\end{array}$ \\
\hline \multicolumn{6}{|l|}{ Phenyl ketones } \\
\hline Acetovanillone & $\begin{array}{l}\text { 1-(4-Hydroxy-3,5- } \\
\text { dimethoxyphenyl)- } \\
\text { ethanone }\end{array}$ & 151/166 & 1487 (a) & $2595(b)$ & Vanilla(i) \\
\hline Propiovanillone & $\begin{array}{l}\text { 1-(4-Hydroxy-3,5- } \\
\text { dimethoxyphenyl)- } \\
\text { propanone }\end{array}$ & 151/180 & $1501^{(\mathrm{a})}$ & $2661^{(b)}$ & Vanilla $^{(n)}$ \\
\hline Butyrovanillone & $\begin{array}{l}\text { 1-(4-Hydroxy-3- } \\
\text { methoxyphenyl)- } \\
\text { butanone }\end{array}$ & 151/194 & 1590(a) & $2770^{(b)}$ & $\begin{array}{l}\text { Caramel, } \\
\text { sweet, } \\
\text { Buttery (i) } \\
\end{array}$ \\
\hline
\end{tabular}




\begin{tabular}{|c|c|c|c|c|c|}
\hline Common name & IUPAC name & \begin{tabular}{|l|}
$\mathrm{m} / \mathrm{z}$ \\
fragment
\end{tabular} & $\begin{array}{l}\text { LRI } \\
\text { Apolar } \\
\text { column }\end{array}$ & \begin{tabular}{|l|} 
LRI \\
Polar \\
column
\end{tabular} & Aroma notes \\
\hline Acetosyringone & $\begin{array}{l}\text { 2-(4-Hydroxy-3- } \\
\text { methoxyphenyl)- } \\
\text { acetaldehyde }\end{array}$ & 181/196 & $1744^{(\mathrm{a})}$ & $2953(\mathrm{~b})$ & \\
\hline Propiosyringone & $\begin{array}{l}\text { 1-(4-Hydroxy-3,5- } \\
\text { dimethoxyphenyl-) } \\
\text { propanone }\end{array}$ & $181 / 210$ & $1753^{(\mathrm{a})}$ & $3010^{(b)}$ & $\operatorname{Vanilla}^{(\mathrm{n})}$ \\
\hline Isoacetosyringone & $\begin{array}{l}\text { 2-(4-Hydroxy-3,5- } \\
\text { dimethoxyphenyl)- } \\
\text { acetaldehyde }\end{array}$ & 167 & $1712^{\text {(a) }}$ & $2927^{(b)}$ & \\
\hline Isopropiosyringone & $\begin{array}{l}\text { 1-(4-Hydroxy-3,5- } \\
\text { dimethoxyphenyl)-2- } \\
\text { propanone }\end{array}$ & 167 & $1785^{(a)}$ & 2979 (b) & \\
\hline \multicolumn{6}{|l|}{ Alcohols } \\
\hline Coniferyl alcohol & $\begin{array}{l}\text { 4-(1-trans)-3-Hydroxy- } \\
\text { prop-1-enyl-2- } \\
\text { methoxyphenol }\end{array}$ & 137 & $1745^{(a)}$ & 3213 (b) & \\
\hline Benzyl alcohol & $\begin{array}{l}\text { Hydroxy } \\
\text { methylbenzene }\end{array}$ & 79,108 & & 1879(p) & Sweet, floral (m) \\
\hline \multicolumn{6}{|c|}{ DERIVED FROM LIPIDS } \\
\hline \multicolumn{6}{|l|}{ Lactones } \\
\hline $\begin{array}{l}\beta \text {-Methyl- } \gamma^{-} \\
\text {octalactone (cis) }\end{array}$ & $\begin{array}{l}\text { cis-4-Methyl-5- } \\
\text { butyldihydro-2(3H)- } \\
\text { furanone }\end{array}$ & 99 & 1325 (a) & 1928 (b) & $\begin{array}{l}\text { Sweet, coconut } \\
\text { (j) woody }(k, l)\end{array}$ \\
\hline $\begin{array}{l}\beta \text {-Methyl- } \gamma- \\
\text { octalactone (trans) }\end{array}$ & $\begin{array}{l}\text { trans-4-Methyl-5- } \\
\text { butyldihydro-2(3H)- } \\
\text { furanone }\end{array}$ & 99 & 1292 (a) & $1861^{(\mathrm{b})}$ & $\begin{array}{l}\text { Sweet, coconut } \\
\text { (j) woody }(k, l)\end{array}$ \\
\hline$\gamma$-Butyrolactone & Dihydro-2(3H)-furanone & 86 & 913(a) & 1593 (b) & Cheese $(\mathrm{m})$ \\
\hline \multicolumn{6}{|l|}{ Acids } \\
\hline Propionic acid & Propanoic acid & 45,74 & 668(g) & & Fruity, floral(q) \\
\hline Butyric acid & Butanoic acid & $60,73,88$ & $827(\mathrm{~g})$ & $1627(\mathrm{~d})$ & $\begin{array}{l}\text { Sweaty, cheesy } \\
\text { unpleasent }(\mathrm{h})\end{array}$ \\
\hline $\begin{array}{l}\text { 3-Methyl butyric } \\
\text { acid }\end{array}$ & 3-Methylbutanoic acid & & $834(\mathrm{~h})$ & $1675^{(\mathrm{r})}$ & $\begin{array}{l}\text { Cheesy, } \\
\text { sweaty }(\mathrm{h})\end{array}$ \\
\hline Valeric acid & Pentanoic acid & $60,73,101$ & & & Strawberry (q) \\
\hline Caproic acid & Hexanoic acid & 60,73 & 982(g) & $1865^{(\mathrm{d})}$ & $\begin{array}{l}\text { Faintly cheesy } \\
\text { sweaty(h) }\end{array}$ \\
\hline Caprylic acid & Octanoic acid & $60,73,144$ & 1163(h) & & $\begin{array}{l}\text { Sweaty, } \\
\text { penetrating }(\mathrm{h})\end{array}$ \\
\hline Capric acid & Decanoic acid & $60,73,172$ & & & Rancid(p) \\
\hline Lauric acid & Dodecanoic acid & $60,73,200$ & & & Soap ${ }^{(\mathrm{f})}$ \\
\hline Myristic acid & Tetradecanoic acid & $43,60,73$ & & & Coconut oil \\
\hline Palmitic acid & Hexadecanoic acid & $43,60,73$ & & 2820 (d) & \\
\hline
\end{tabular}




\begin{tabular}{|c|c|c|c|c|c|}
\hline Common name & IUPAC name & \begin{tabular}{|l|}
$\mathrm{m} / \mathrm{z}$ \\
fragment
\end{tabular} & $\begin{array}{l}\text { LRI } \\
\text { Apolar } \\
\text { column }\end{array}$ & \begin{tabular}{|l|} 
LRI \\
Polar \\
column
\end{tabular} & Aroma notes \\
\hline \multicolumn{6}{|c|}{ DERIVED FROM CAROTENOIDS } \\
\hline \multicolumn{6}{|l|}{ Norisoprenoids } \\
\hline$\beta$-Ionone & $\begin{array}{l}\text { 4-(2,6,6-Trimethyl- } \\
\text { cyclohex-1-enyl)-but-3- } \\
\text { en-2-one }\end{array}$ & \begin{tabular}{|l|}
43, \\
177,192
\end{tabular} & & 1614 (c) & Violet $(\mathrm{m})$ \\
\hline 3-Oxo-a-ionol & $\begin{array}{l}\text { 9-Hydroxymegastigma- } \\
\text { 4,7-dien-3-one }\end{array}$ & 108 & 1648 (a) & $\begin{array}{l}2518^{(b)} \\
2658(d) \\
1937(c)\end{array}$ & \\
\hline Blumenol C & $\begin{array}{l}\text { 4-(3-Hydroxybutyl)- } \\
\text { 3,5,5-trimethyl-cyclohex- } \\
\text { 2-en-1-one }\end{array}$ & $41,43,108$ & & 2002 (c) & \\
\hline $\begin{array}{l}\text { Blumenol A } \\
\text { (vomifoliol) }\end{array}$ & $\begin{array}{l}\text { 6,9- } \\
\text { Dihydroxymegastigma- } \\
\text { 4,7-dien-3-one }\end{array}$ & $\begin{array}{l}189,207 \\
224\end{array}$ & & 2180 (c) & \\
\hline Vitispirane & $\begin{array}{l}\text { 2,6,6-Trimethyl-10- } \\
\text { methyliden-1- } \\
\text { oxospiro[4,5]dec-7-ene }\end{array}$ & & 1286(e) & 1327 (c) & $\begin{array}{l}\text { Floral, } \\
\text { fruity, earthy, } \\
\text { woody } \\
\end{array}$ \\
\hline 3-Oxo-retro- $a$-ionol & $\begin{array}{l}\text { 9-hidroximegastigma- } \\
\text { 4,6-dien-3-one } \\
\text { (cis and trans) }\end{array}$ & & & $\begin{array}{l}2001^{(\mathrm{c})} \\
2081^{(\mathrm{c})} \\
2797(\mathrm{~d})\end{array}$ & \\
\hline
\end{tabular}

(a)DB5 column, Fernandez de Simon et al., 2009 ; (b)Carbowax column, Fernandez de Simon et al., 2009; (c)DB1701 (medium polar) column, Sefton et al., 1990; (d)Stabilwax column, Natali et al., 2006 (e)HP5 column, Jordão et al.,2006; (f)DBwax column, Caldeira et al.,2008; (g)HP5 column, Vichi et al., 2007; (h) SPB1 column, Diaz-Maroto et al., 2008; (i)Rodriguez-Bencomo et al., 2009; (i)Mosedale \& Puech, 1998; (k)Piggott et al., 1995; ()Garde-Cerdán \& Ancín-Azpilicueta , 2006a (m)Sáenz-Navajas et al., 2010; (n) Togores, 2004; (o)Gomes da Silva \& Chaves das Neves, 1999; (p) Zhao et al, 2011 (q) Cormier et al. 1991; (r)Barata et al., 2011

Table 1. Main volatile compounds formed from wood biopolymer during toasting process. LRI denotes linear retention indexes; $m / z$ denotes mass fragment ions and base peak is presented in bold.

The intensity and length of the applied heat affects the production of compounds during macromolecules degradation and define the toasting levels. Designations like untoasted, light, medium and heavy toast are common, but there is no industry standard for toast level.

According to Vivas et al. (1991) the quality and quantity of each volatile compound are strongly related with toasting intensity, but particular characteristics of each species can also determine the rate of modification during toasting process. For instance, when comparing volatile composition of $Q$. pyrenaica and $Q$. petraea wood chips, the increase amount of compounds with the toasting process was less evident in the Portuguese oak (Jordão et al., 2006). These authors pointed out that physical properties and structure of wood may influence heat conduction and reactions upon heating. Caldeira et al., (2006 b) also found that as toasting intensity increases, concentration of the majority of volatile compounds found in wood matrix rises. In several oak species, as well as in Portuguese chestnut, 
increasing toasting level led to an increase of furanic aldehydes, volatile phenols, 4-hydroxybut-2-en-lactone and vanillin (Caldeira et al., 2006 b)

It is also relevant that the response of a wood to a particular seasoning and toasting condition is determined by the size of the wood piece, as it affects their structural properties, and hence, the flavour characteristics. Moreover, each piece size shows different extraction kinetics when in contact with wines (Fernández de Simón et al., 2010 b).

Indeed, when heat is applied to wood, a depolymerization of the lignin takes place producing phenolic aldehydes. Therefore, their concentration increases with toast level. Toasting also produce the cleavage of $\alpha-\beta$ bonds of cinnamic aldehydes and their thermooxidation and thermo-decarboxylation, leading to the formation of dimethoxyphenyl units such as syringol, and in heavy toast, to simple phenols as phenol and $o$-cresol (Nonier et al., 2006).

Toasting is such an important parameter that the characteristic profile of a toasted wood is completely different from the untoasted wood. The particular characteristics of macromolecules, lignin, cellulose, hemicellulose and lipids in each wood have a great influence on the volatiles composition of toasted woods. Fernández de Simón et al., (2009) concluded that toasting led to an increase in almost all the compounds when compared to untoasted woods. These increases were more evident in acacia, chestnut and ash woods, concerning lignin, lipids and carbohydrate derivatives. Cherry and ash woods were found to be richer than toasted oak in lignin derivatives, but much poorer in lipid and carbohydrate derivatives.

\section{Analytical methodologies for quantification and identification of volatiles compounds from woods}

\subsection{Sample preparation methods}

Wine aroma is a very complex matrix comprising an enormous variety of compounds of many chemical families. Not all of them are odour active compounds, which imply the necessity of a target strategy in order to isolate the compounds of interest from the aqueous/alcoholic matrix.

Frequently, prior to analysis, samples are submitted to a preliminary preparation step, including isolation and concentration of the target compounds. The more used extraction and enrichment technique are liquid-liquid extraction (LLE), solid-phase extraction (SPE) and headspace, comprising the static/equilibration method (HS) and the dynamic method (purge \& trap - P\&T). These techniques have been recently reviewed by Costa Freitas et al. The quality of the subsequent analysis and results, depend largely on the isolation procedures. Different preparation methodologies might affect the final extract composition for the very same matrix. Nowadays researchers are focusing their attention not only to the extraction efficiency, of the methods used, but also to sustainable methods and thus more environmental friendly. Considering this, miniaturization has been applied and micro-LLE methods, such as dispersive liquid-liquid extraction (DLLME) (Fariña et al., 2007) or pressurized solvent extraction (Natali et al., 2006, Vichi et al., 2007), solid phase micro extraction methods (SPME) (Cai et al., 2009) and single drop microextraction (SDME) 
(Martendal et al., 2007; Sillero et al., 2011) arise as prominent techniques for isolation of compounds in several liquid and solid matrices. Special attention has been given to methods which preclude the use of solvents, such as SPME (Bozalongo et al., 2007) and stir bar sorptive extraction (SBSE) (Marín et al., 2005; Tredoux et al., 2008; Rojas et al., 2009). These methods increase, in the case of gas chromatography (GC), the quality of the resulting chromatogram, allowing the detection of several volatile compounds that would, otherwise, be hidden under the solvent peak. As a definition one might state that preparation methods should be reproducible, and should provide an extract, as much as possible, similar to the original matrix.

Extracts obtained after exhaustive extraction techniques, which include solvent extraction and distillation, normally do not reflect the real matrix aroma profile, since they isolate compounds according, simultaneously, to solubility in the used solvent and volatility, considering the matrix properties (e.g. water or alcohol content). These methods provide a profile that reflects the volatile and semi-volatile composition of matrix rather then "real" aroma compounds of the matrix. Moreover, literature also agree, that only a small fraction of the isolated compounds can be correlated with sensory notes of the matrices (Plutowska \& Wardencki, 2008). Consequently HS-based methods are currently the most used ones, since they allow the target isolation of the released volatiles from the matrix.

\subsubsection{Extraction methods using solvents}

In the analysis of wine aroma, the most used solvent extraction methods are LLE (Ortega et al., 2001; Garde-Cerdán \& Ancín-Azpilicueta, 2006b), micro-wave assisted extraction (MAE) (Serradilla \& de Castro, 2011), ultrasound assisted extraction (UAE) (Cocito et al., 1995; Fernandes et al., 2003), PLE (Natali et al., 2006; Vichi et al., 2007) and SPE (Morales et al., 2004; Campo et al 2007, Weldegergis et al., 2011). The type and quantity of the used organic solvent varies according to the methodology. In order to perform a classical LLE, eventually, a generous amount of solvent is used, and that is the reason why MAE, UAE and PLE became more popular, since the total amount of solvent can be significantly reduced. Prefractionation of the extract can also be subsequently performed (Fernandes et al, 2003) in order to simplify the extract for chromatographic analysis. Nevertheless, in all techniques, the obtained organic extract must be concentrated in order to be chromatographically analyzed. If gas chromatography hyphenated with olfactometry (GC-O) is going to be used, the organic extract should be rinsed with aqueous solutions, at different $\mathrm{pH}$, in order to eliminate the presence of non-volatile compounds which are also extracted during the isolation process (Plutowska \& Wardencki, 2008). The final extract has to be free of compounds which can produce artifacts during injection into the hot injector of the GC instrument, such as amino acids or fatty acids. The latter present a prolonged odor in the olfactometric port which can falsify the results of the analytes eluting subsequently. Thus a clean-up with resins should be performed. Before analysis a concentration step is also needed, in order to evaporate the excess of solvent prior to the chromatographic analysis. With this necessary step one can simultaneously promote the evaporation of the more volatile compounds and, eventually, odor components degradation, through oxidation processes, since air contact is almost unavoidable. Thus the final extract will not reproduce the original aroma matrix. 


\subsubsection{Solvent-less extraction methods}

Extraction methods precluding the use of solvents have the main advantage of, in a single step, promoting extraction, isolation and concentration of the target compounds, without any other manipulation. At the same time, since it relies in the headspace of a sample, they will, indeed, mirroring the original sample and thus representing the true olfactory perception. This technique can be used in static or dynamic modes, or at a limit, the sample itself can be submitted to direct analysis without any previous treatment. In static mode, after reaching equilibrium, although not necessarily, sampling takes place and, normally, the more volatile compounds are successfully detected. Less volatile compounds, on the other, and depending on their individual vapour pressure, might be also detected. To overcome this drawback, dynamic sampling can be used. Here, purge \& trap techniques, in which the compounds of interest are trapped in a suitable adsorbent are the most used. After sampling the trapped compounds can be directly desorbed, by means of a thermal desorber injector, or an extraction with a suitable solvent, before analysis, can be performed. Except for this latter case, the sample is completely lost after analysis, and no repeats are possible. However, no solvent peak is obtained, allowing detection of the more volatile components that, otherwise, could be co-eluting with the solvent peak. Other drawbacks of the dynamic mode should also be mentioned, namely the impact of the chemical nature of the adsorbent, on the trapped compounds. The most used trap materials are Tenax TA, Porapak $Q$ and Lichrolut EN, since their affinity for ethanol is small (Escudero et al., 2007; Weldegergis et al, 2011). After the introduction of SPME (Belardi \& Pawliszyn, 1989; Arthur \& Pawliszyn, 1990), most of the HS methods started to use this method to perform aroma analysis. The obvious advantages of SPME are the fact that it does not involve critical sample manipulations. SPME is a simple and clean extraction method, comprising in a single step, all the necessary steps mandatory in aroma analysis: extraction, isolation and concentration (Rocha et al., 2007). In this technique, depending on the fibre physico-chemical properties (chemical nature and thickness), target analysis is, somehow, possible. However if a wide screening of the sample is aimed, more than one type of fibre should be tested. SPME demands a careful optimization of the experimental conditions in order to be used for qualitative and quantitative studies. The efficiency, accuracy and precision of the extraction methodology is directly dependent on extraction time, sample agitation, $\mathrm{pH}$ adjustment, salting out, sample and/or headspace volume, temperature of operation, adsorption on container walls and desorption conditions (Pawliszyn, 1997) besides fibre coating and thickness.

\subsection{Chromatographic methods}

The contact between wines and wood during the fermentation or storage process is a common practice in wine making. In order to improve the organoleptic characteristics of wine, storage in wood based barrels or the addition of wood chips is used in their natural form or after seasoning and thermal treatment by toasting or charring. The wood types for enological purposes comprises cherry, acacia, chestnut, mulberry, and especially, oak. Together with changes in colour and taste, the aroma of the resulting wine product is strongly affected (Garde-Cerdán \& Ancín-Azpilicueta, 2006a). The porous nature of wood, promotes oxidation reactions, forming a wide variety of volatile compounds, otherwise not 
present in the final product. Some compounds are also directly extracted into the wine during the long lasting contact between the wood and the wine. Together with endogenous volatile compounds, they contribute to the final wine bouquet. The most representative compounds, which reflect the wood influence in wine aroma, are furfural derivates, such as furfural, 5-methylfurfural and furfuryl alcohol, phenolic aldehydes and ketones, such as vanillin and acetovanillone and a large variety of volatile phenols, such as guaiacol, 4ethylphenol, 4-ethylguaiacol, 4-vinylphenol, 4-vinylguaiacol and eugenol and also phenolic acids (Tredoux et al., 2008; Weldergegis et al., 2011). The two oak lactones isomers, cis- and trans- $\beta$-methyl- $\gamma$-octalactone and $\gamma$-nonalactone are also present, especially if wood has been submitted to a previous seasoning or toasting process (Carrillo et al., 2006). Because they possess a very low sensory threshold, even in very low concentration, they strongly influence the final aroma. Liquid chromatographic (LC) methods, like capillary electrophoresis (CE) (Sádecká \& Polonský, 2000), high performance liquid chromatography (HPLC) and ultra performance liquid chromatography (UPLC) are suitable methods to be used in order to separate, detect and quantify the above mentioned chemical classes, as recently reviewed (Cabrita et al., 2008; Kalili \& de Villiers, 2011). The strong aromatic ring chromophore allows ease and sensitive detection by ultra-violet-visible (UV) detection devices or by mass spectrometry (MS). UPLC also reached better limits of detection (LOD) in the low ppb range, ten times higher for phenol compounds and furanic derivatives, when compared with HPLC methods (Chinnici et al., 2007). Considering the long-term storage in charred barrels, the presence of polycyclic aromatic hydrocarbons (PAHs) in aged alcoholic beverages has been proposed as an emerging issue. Although the transference rate, to the hydro-alcoholic mixture, of these high hydrophobic compounds is expected to be low, LODs less then $1 \mathrm{ppb}$ are achievable when LC techniques are coupled with fluorimetric detection. Since the majority of the above mentioned compound classes are semi-volatile compounds, together with the endogenous compounds present in the wine, wine becomes an even more complex matrix to be analyzed as a whole. Therefore the analytical methodologies should be sufficiently powerful and sensitive to separate and detect hundreds of compounds of quite different concentrations and volatilities. The advent of gas chromatography (GC) significantly enhanced the systematic study of wine aroma, and its use, particularly when combined with mass spectrometry (MS), contributed significantly to the knowledge of wine volatile composition. Extracts from acacia, chestnut, cherry, mulberry, and oak wood, used in barrels for wine and spirits aging, have already been studied by GC/MS positive ion chemical ionization (PICI). These method, using methane as reagent gas, produce a high yield of the protonated molecular ion of volatile phenols, and allows compounds identification to be confirmed by collision-induced-dissociation (CID) experiments on $[\mathrm{M}+\mathrm{H}]^{+}$species. MS/MS fragmentation patterns can be studied with standard compounds giving more accurate results (Flamini et al., 2007).

Considering that the human nose is still the best detector for aroma active compounds, the hyphenation of GC with olfactometry (GC-O) is mandatory, when sensorial activity, of individual compounds, and the knowledge of the relations between the perceived odour and chemical composition, of the volatile fraction, is searched. In GC-O detection is performed by an educated panel of persons and the qualitative and quantitative evaluation of the odour is carried out for each single compound eluting from the chromatographic 
column. For a given compound a relationship is established between its sensorial activity at a particular concentration (if above the threshold of sensory detection) and its smell, as well as the determination of the time period of sensory activity and the intensity of the odor. This is possible if in parallel to a conventional detector, e.g. flame ionization detector (FID), MS or even a flame photometric detection (FPD) for sulfur speciation (Chin et al., 2011), an olfactometric port is attached to the instrument in order to determine the compound odor. The splitted flow carries the compounds simultaneously to both detection devices, allowing the comparison between each obtained signals. The mass structural information obtained by MS spectra allows the identification of odour active compounds. The quantitative evaluation of the intensity of the odours can be divided in three groups: detection frequency (where NIF - Nasal Impact Frequency values or SNIF - Surface of Nasal Impact Frequency are measured), dilution to threshold (CHARM method - Combined Hedonic Aroma Response Measurement and AEDA - Aroma Extract Dilution Analysis) and finally direct intensity methods (where the intensity of the stimuli and its duration are measured - OSME - Olfactometry by Finger Span Method). All these methods were carefully revised by Plutowska \& Wardencki (2008).

It is easily recognizable that GC is the most appropriate instrumental approach, for wine aroma analysis. However, the enormous quantity of peaks obtained together with the similarity of retention factors of many related components means that component overlap will be the general expectation, meaning that complete separation may be largely unachievable for a given extract. In order to improve analysis, new separation technologies should be embraced. It is desirable to increase peak capacity and thus increasing the probability of locating a greater number of baseline resolved components within the chromatographic run. Together with new stationary phases (more thermal and chemically stable and enantioselective) and faster detection systems, this will largely enhance results quality. Multidimensional chromatographic (MD) methods are emerging as important alternatives to analyze such complex matrix, as wines. Whether using the heart-cutting mode (MD-GC) (Campo et al., 2007; Schmarr et al., 2007; Pons et al., 2008), enantio-MDGC (Darriet et al, 2001; Culleré et al., 2009) or comprehensive two-dimensional GC (2D-GC) approach (GC × GC) (Ryan et al., 2005; Rocha et al., 2007; Torres et al., 2011; Weldegergis et al., 2011), MD methods allow the combination of two or more independent, or nearly independent, separation steps, increasing significantly the separation power of the corresponding one-dimensional (1D-GC) techniques and, therefore the physical separation of compounds in complex samples. When coupled with a preparative fraction collection device (selectable 1D/2D GC-O/MS with PFC) one can perform the enrichment of trace compounds with an high odourific impact (Ochiai \& Sasamoto, 2011) in order to eventually proceed to further identification by NMR (Marriott et al., 2009). In order to overcome matrix complexity, a further dimensionality can be coupled to achieve separation efficiency. Methoxypyrazines were analyzed by LC-MDGC/MS (Schmarr et al., 2010a), nevertheless the complexity and price of the instrumental set-up encourages more research in this domain. 2D-LC $\times$ LC methods (Cacciola et al., 2007, Dugo et al., 2008; Cesla et al. 2009) are also replacing the traditional 1D-LC separation modes, especially in what phenolic volatile concerns. This technique improves the separation of non-volatile polyphenols (Kivilompolo et al., 2008), and allows ease switch between LC and LC $\times$ LC during a single analysis providing a better separation target, only, to the most complex part of the chromatogram. 
Additionally to the enhanced separations achieved by 2D methods, comprehensive GC and LC also allow an easy comparison between samples, since the obtained chromatograms can be easily inspected for compound markers in quality control, certification and fraud detection. In fact, the probability of correctly determining a particular sample substance is increased, by the correlation of two or more independent data sets, in complex sample analysis. To generate these two sets of data, analysis has to be performed, individually, in two orthogonal columns phases, e.g. non-polar and a polar column for the case or GC $\times$ GC or e.g. exclusion and a reversed-phase column in LC $\times$ LC. Although this practice improves the quantitative data for key target components, it is often difficult, and may be tedious, to correlate the retention times for all of the peaks from the individual chromatograms. In any 2D chromatogram retention time data from the two independent stationary phases are immediately available. Thus a 2D chromatogram contains much more information than two independent 1D chromatograms. 2D analysis offers a genuine opportunity to characterize individual components based on retention time data alone, provided that high reproducibility of retention times can be achieved, reducing and eventually precluding, the requirement of MS detection for many samples. The reliability of peak position co-ordinates opens the possibility of fingerprinting comparison or statistical treatment in order to characterize the effects of distinct types of wood, the same wood from different origins, or even aging time (Cardeal et al., 2008; Vaz-Freire, 2009; Schmarr et al., 2010 b; Schmarr \& Bernhardt, 2010).

\section{Conclusion}

Each wood species has a characteristic profile, regarding their volatile composition. Heating during processing of wood to be used in cooperage, specially toasting, has a great influence on biopolymers degradation, thus the resulting compounds. The volatile profile of an untoasted wood can be different from the same wood after toasting. Increasing toasting levels generally leads to an increase of volatile compounds but some can also suffer degradation. Compounds released from wood into wine or spirits depends on several factors such as type of wood, size of alternatives (e.g. chips and staves), time of contact, but also depends on the chemical characteristics of the beverage, specially the alcohol content.

Recent development in 2D analytical approaches, together with more sensitive and fast mass spectrometers, allow to gain insight in the volatile fraction of the wine/wood interaction system, aiming wine quality.

\section{Acknowledgment}

Authors wish to thank Fundação para a Ciência e Tecnologia, Ministério da Ciência, Tecnologia e Ensino Superior and Programa Operacional Ciência e Inovação for financial support PTDC/QUI-QUI/100672/2008.

\section{References}

Ancín-Azpilicueta, C.; Garde-Cerdán T.; Torrea, D. \& Jimenez, N. (2004). Extraction of volatile compounds in model wine from different oak woods: Effect of $\mathrm{SO}_{2}$. Food Research International, Vol. 37, pp. 375-383. 
Arapitsas, P.; Antonopoulos, A.; Stefanou, E. \& Dourtoglou, V.G.(2004). Artificial aging of wines using oak chips. Food Chemistry, Vol.4, pp. 563-570

Arthur, C. \& Pawliszyn, J. (1990). Solid Phase Microextraction with Thermal Desorption Using Fused Silica Optical Fibers. Analytical Chemistry, Vol.62, pp. 2145-2148

Barata, A.; Campo, E; Malfeito-Ferreira, M.; Loureiro, V; Cacho, J. \& Ferreira, V. (2011). Analytical and Sensorial Characterization of the Aroma of Wines Produced with Sour Rotten Grapes Using GC-O and GC-MS: Identification of Key Aroma Compounds. Journal of Agricultural and Food Chemistry, Vol. 59, pp. 2543-2553

Bautista-Ortín, A.B.; Lencina, A.G.; Cano-López, M.; Pardo-Minguez, F.; López-Roca, J.M. \& Gómez-Plaza, E. (2008). The use of oak chips during the ageing of a red wine in stainless steel tanks or used barrels: Effect of the contact time and size of the oak chips on aroma compounds. Australian Journal of Grape and Wine Research, Vol. 14, pp. 63-70.

Belardi, R. P. \& Pawliszyn, J. B. (1989). The Application of Chemically Modified Fused Silica Fibers in the extraction of Organics from Water Matrix Samples and their Rapid Transfer to capillary columns. Water Pollution Research Journal of Canada, Vol.24, pp. 179-189

Bozalongo, R.; Carrillo, J. D.; Torroba, M. A. F. \& Tena, M. T. (2007). Analysis of French and American oak chips with different toasting degrees by headspace solid-phase microextraction-gas chromatography-mass spectrometry. Journal of Chromatography A, Vol.1173, pp. 10-17

Cabrita, M.J.; Torres, Ma .; Palma, V.; Alves, E.; Patão, R.; Costa Freitas, A. Ma . (2008). Impact of Malolactic Fermentation on Low Molecular Weight Phenolic Compounds. Talanta, Vol. 74, pp. 1281-1286

Cacciola, F.; Jandera, P.; Hajduá, Z.; Cĕsla, P. \& Mondello, L. (2007). Comprehensive twodimensional liquid chromatography with parallel gradients for separation of phenolic and flavone antioxidants. Journal of Chromatography A, Vol.1149, pp. 73-87

Cadahía, E.; Fernández de Simón, B.; \& Jalocha, J. (2003). Volatile compounds in Spanish, French, and American oak woods after natural seasoning and toasting. Journal of Agricultural and Food Chemistry, Vol. 51, pp. 5923-5932.

Cadahía, E.; Muñoz, L.; Fernández de Simón, B. \& García-Vallejo, M. C. (2001). Changes in low molecular weight phenolic compounds in Spanish, French, and American oak woods during natural seasoning and toasting. Journal of Agricultural and Food Chemistry, Vol. 49, pp. 1790-1798.

Cai, L.; Koziel, J. A.; Dharmadhikarib, M. \& van Leeuwenc, J. (H). (2009). Rapid determination of trans-resveratrol in red wine by solid-phase microextraction with on-fiber derivatization and multidimensional gas chromatography-mass spectrometry. Journal of Chromatography A, Vol.1216, pp. 281-287

Caldeira, I.; Anjos, O.; Portal, V.; Belchior, A.P. \& Canas, S. (2010). Sensory and chemical modifications of wine-brandy aged with chestnut and oak wood fragments in comparison to wooden barrels. Analytica Chimica Acta, Vol. 660, pp. 43-52 
Caldeira, I.; Bruno de Sousa, R.; Belchior, A.P. \& Clímaco, M.C. (2008). A sensory and chemical approach to the aroma of wooden aged Lourinha wine brandy. Journal of Viticulture and Enology, Vol.23, pp.97-110

Caldeira, I.; Pereira, R.; Clímaco, M.C.; Belchior, A.P. \& Bruno de Sousa, R. (2004). Improved method for extraction of aroma compounds in aged brandies and aqueous alcoholic wood extracts using ultrasound. Analytica Chimica Acta, Vol. 513, pp. $125-134$

Caldeira, I.; Clímaco, M.C.; Bruno de Sousa, R. \& Belchior A.P. (2006 b) Volatile composition of oak and chestnut woods used in brandy ageing: modification induced by heat treatment. Journal of Food Engineering, Vol. 76, pp. 202-211

Caldeira, I.; Mateus, A.M. \& Belchior A.P. (2006 a). Flavour and odour profile modifications during the first five years of Lourinhâ brandy maturation on different wooden barrels. Analytica Chimica Acta, Vol. 563, pp. 265-273

Campo, E.; Cacho, J. \& Ferreira, V. (2007). Solid phase extraction, multidimensional gas chromatography mass spectrometry determination of four novel aroma powerful ethyl esters. Assessment of their occurrence and importance in wine and other alcoholic beverages. Journal of Chromatography A, Vol.1140, pp. 180-188

Cardeal, Z. L.; de Souza, P. P.; Gomes da Silva, M. D. R. \& Marriott, P. J. (2008). Comprehensive two-dimensional gas chromatography for fingerprint pattern recognition in cachaça production. Talanta Vol.74, pp. 793-799

Carrillo, J.D.; Garrido-López, A. \& Tena, M.T. (2006) Determination of volatile oak compounds in wine by headspace solid-phase microextraction and gas chromatography-mass spectrometry Journal of Chromatography A, Vol. 1102, pp. 2536

Cĕsla, P. Hájek, T. \& Jandera, P. (2009). Optimization of two-dimensional gradient liquid chromatography separations. Journal of Chromatography A, Vol. 1216, pp. 34433457

Chatonnet, P. \& Dubourdieu, D. (1998) Comparative study of the characteristics of American white oak (Quercus alba) and European oak (Quercus petraea and Q. robur) for production of barrels used in barrel aging of wines. American Journal of Enology and Viticulture, Vol 49, pp. 79-85.

Chatonnet, P. ; Cutzach, I. ; Pons, M. \& Dubourdieu, D. (1999). Monitoring toasting intensity of barrels by chromatographic analysis of volatile compounds from toasted oak wood. Journal of Agricultural and Food Chemistry, Vol. 47, pp. 4310-4318.

Chin, S. T.; Eyres, G. T. \& Marriott, P. J. (2011). Identification of potent odourants in wine and brewed coffee using gas chromatography-olfactometry and comprehensive two-dimensional gas chromatography. Journal of Chromatography A. Vol. 1218, pp.7487-7498

Chinnici, F.; Natali, N.; Spinabelli, U. \& Riponi, C. (2007). Presence of polycyclic aromatic hydrocarbons in woody chips used as adjuvant in wines, vinegars and distillates LWT, Vol. 40, pp. 1587-1592

Cormier, F.; Raymond, Y.; Champagne, C. P. \& Morin, A. (1991). Analysis of odor-active volatiles from Pseudomonas fragi grown in milk. Journal of Agricultural and Food Chemistry, Vol. 39, pp. 159-161. 
Costa Freitas, A. M.; Gomes da Silva, M. D. R. \& Cabrita M. J. (accepted). Extraction Techniques and Applications: Food and Beverage. Sampling techniques for the determination of volatile components in grape juice, wine and alcoholic beverages", in Comprehensive Sampling and Sample Preparation, J. Pawliszyn (Editor), Elsevier

Cocito, C.; Gaetano, G. \& Delli, C. (1995). Rapid extraction of aroma compounds in must and wine by means of ultrasound. Food Chemistry, Vol.52, pp. 311-320

Culleré, L.; Escudero, A.; Campo, E.; Cacho, J. \& Ferreira V. (2009). Multidimensional gas chromatography-mass spectrometry determination of 3-alkyl-2methoxypyrazines in wine and must. A comparison of solid-phase extraction and headspace solid-phase extraction methods. Journal of Chromatography A, Vol.1216, pp. 4040-4045

Cutzach, I. ; Chatonnet, P. ; Henry, R. \& Dubourdieu, D. (1997). Identification of volatile compounds with a "toasty" aroma in heated oak used in barrelmaking. Journal of Agricultural and Food Chemistry, Vol. 45, pp. 2217-2224.

Darriet, P.; Lamy, S.; La Guerche, S.; Pons, M.; Dubourdieu, D.; Blancard, D.; Steliopoulos, P. \& Mosandl, A. (2001). Stereodifferentiation of geosmin in wine European Food Research E Technology, Vol.213, pp. 122-125

de Rosso, M.; Cancian, D.; Panighel, A.; Vedova, A.D. \& Flamini, R. (2009). Chemical composition released from five different woods used to make barrels for aging wines and spirits: volatile compounds and polyphenols. Wood Science Technology, Vol 43, pp. 375-385

Díaz-Maroto, M.C.; Guchu, E.; Castro-Vásquez, L.; de Torres, C. \& Pérez-Coello, M.S. (2008) Aroma-active compounds of American, French, Hungarian and Russian oak woods, studied by GC-MS and GC-O. Flavour and Fragance Journal, Vol.23, pp. 93-98

Doussot, F. ; De Jeso, B. ; Quideau, S. \& Pardon, P. (2002). Extractives content in cooperage oak wood during natural seasoning and toasting; influence of tree species, geographic location, and single-tree effect. Journal of Agricultural and Food Chemistry, Vol. 50, pp. 5955-5961.

Dugo, P.; Cacciola, F. Herrero, M.; Donato, P. \& Mondello, L. (2008). Use of partially porous column as second dimension in comprehensive two-dimensional system for analysis of polyphenolic antioxidants. Journal of Separation Science, Vol.31, pp. 32973308

Escalona, H.; Birkmyre, L.; Piggot, J.R. \& Paterson, A. (2002) Effect of maturation in small oak casks on the Volatility of red wine aroma compounds. Analytica Chimica Acta, Vol. 458, pp. 45-54

Escudero, A.; Campo, E.; Fariña, L.; Cacho, J. \& Ferreira, V. (2007). Analytical Characterization of the Aroma of Five Premium Red Wines. Insights into the Role of Odor Families and the Concept of Fruitiness of Wines. Journal of Agricultural and Food Chemistry, Vol.55, pp. 4501-4510

Fariña, L.; Boido, E.; Carrau, F. \& Dellacassa, E. (2007). Determination of volatile phenols in red wines by dispersive liquid-liquid microextraction and gas chromatography-mass spectrometry detection. Journal of Chromatography A, Vol.1157, pp. 46-50 
Fernandes, L.; Relva, A. M.; Gomes da Silva, M. D. R. \& Costa Freitas, A. M. (2003). Different multidimensional chromatographic approaches applied to the study of wine malolactic fermentation. Journal of Chromatography A, Vol. 995, pp. 161-169

Fernández de Simón, B.; Muiño, I. \& Cadahía, E. (2010a). Characterization of volatile constituints in commercial oak wood chips. Journal of Agricultural and Food Chemistry, Vol. 58, pp. 9587-9596

Fernández de Simón, B.; Cadahía, E.; del Álamo, M. \& Nevares, I. (2010b) Effect of size, seasoning and toasting in the volatile compounds in toasted oak wood and in a red wine treated with them. Analytica Chimica Acta, Vol. 660 pp. 211-220

Fernández de Simón, B.; Esteruelas, E.; Muñoz, A.M.; Cadahía, E. \& Sanz, M. (2009). Volatile Compounds in Acacia, Chestnut, Cherry, Ash, and Oak Woods, with a View to Their Use in Cooperage. Journal of Agricultural and Food Chemistry, Vol. 57,pp. 32173227

Ferreras, D.; Fernández, E. \& Falqué, E. (2002) Note: Effects of oak wood on the aromatic composition of Vitis vinifera L. var. treixadura wines. Food Science and Technology International, Vol. 8, pp. 343-349

Flamini, R.; Vedova, A.D.; Cancian, D.; Panighel, A. \& de Rosso, M. (2007) GC/MS-positive ion chemical ionization and MS/MS study of volatile benzene compounds in five different woods used in barrel making. Journal of Mass Spectrometry, Vol.42, pp.641646

Frangipane M.Y.; de Santis, D. \& Ceccarelli, A. (2007) Influence of oak woods of different geographical origins on quality of wines aged in barriques and using oak chips. Food Chemistry, Vol.103, pp. 46-54

Garde-Cerdán, T., \& Ancín-Azpilicueta, C. (2006a). Review of quality factors on wine ageing in oak barrels. Trends in Food Science ETechnology, Vol.17, pp. 438-447

Garde-Cerdán, T., \& Ancín-Azpilicueta, C. (2006b). Effect of oak barrel type on the volatile composition of wine: Storage time optimization. Lebensmittel-Wissenschaft undTechnologie,Vol. 39, pp. 199-205

Garde-Cerdán, T.; Rodríguez-Mozaz, S. \& Ancín-Azpilicueta, C. (2002). Volatile composition of aged wine in used barrels of French oak and of American oak. Food Research International, Vol. 35, pp. 603-610

Garde-Cerdán, T.; Torrea-Goñi, D. \& Ancín-Azpilicueta, C. (2004). Acumulation of volatile compounds during ageing of two red wines with different composition. Journal of Food Engineering, Vol. 65, pp. 349-356

Giménez-Martínez, R.; López-García de la Serrana, H.; Villalón-Mir, M.: Quesada-Granados, J. \& López-Martínez, M. C. (1996). Influence of wood heat treatment, temperature and maceration time on vanillin, syringaldehyde, and gallic acid contents in oak word and wine spirit mixtures. American Journal of Enology and Viticulture, Vol. 47, pp. 441-446.

Gomes da Silva, M. D. R. \& Chaves das Neves, H. J. (1999). Complementary Use of Hyphenated Purge-and-Trap Gas Chromatography Techniques and Sensory Analysis in the Aroma Profiling of Strawberries (Fragaria ananassa). Journal of Agricultural and Food Chemistry, Vol. 47, pp. 4568-4573. 
Gómez-Plaza, E.; Pérez-Prieto, L.J.; Fernández-Fernández, J.I. \& López-Roca, J. M. (2004). The effect of successive uses of oak barrels on the extraction of oak-related volatile compounds from wine. International Journal of Food Science \& Technology, Vol. 39, pp. 1069-1078.

Guchu, E.; Díaz-Maroto, M.C.; Pérez-Coello, M.S.; González-Viñas, M.A.; Cabezudo Ibáñez, M.D. (2006) Volatile composition and sensory characteristics of Chardonnay wines treated with American and Hungarian oak chips. Food Chemistry, Vol. 99, pp. 350359

Jarauta, I.; Cacho, J. \& Ferreira, V. (2005). Concurrent phenomena contributing to the formation of the aroma of wine during aging in oak wood: An analytical study. Journal of Agricultural and Food Chemistry, Vol. 53, pp. 4166-4177

Jiménez-Moreno, N. \& Ancín-Azpilicueta, C. (2007). Binding of oak volatile compounds by wine lees during simulation of wine ageing. Lebensmittel-Wissenschaft undTechnologie,Vol. 40, pp. 619-624.

Jiménez-Moreno, N.; González-Marco, A. \& Ancín-Azpilicueta, C. (2007). Influence of wine turbidity on the accumulation of volatile compounds from the oak barrels. Journal of Agricultural and Food Chemistry, Vol. 55, pp. 6244-6251.

Jordão, A.M.; Ricardo da Silva, J.; Laureano, O.; Adams, A.; Demyttenaere, J.; Verhè, R. \& De Kimpe, N. (2006). Volatile composition analysis by solid-phase microextraction applied to oak wood used in cooperage (Quercus pyrenaica and Quercus Petraea): effect of botanical species and toasting process. Journal of Wood Science, Vol. 52, pp. 514-521

Kalili, K. M. \& de Villiers, A. (2011). Recent developments in the HPLC separation of phenolic compounds. Journal of Separation Science, Vol.34, pp. 854-876

Kivilompolo, M.; Obůrka, V. \& Hyötyläinen, T. (2008). Comprehensive two-dimensional liquid chromatography in the analysis of antioxidant phenolic compounds in wines and juices. Analytical \& Bioanalytical Chemistry, Vol.391, pp. 373-380

Madrera, R.R.; Gomis, D.B. \& Alonso J.J.M. (2003). Influence of Distillation System, Oak Wood Type, and Aging Time on Volatile Compounds of Cider Brandy. Journal of Agricultural and Food Chemistry, Vol. 51, pp. 5709-5714

Marco, J.; Artajona, J.; Larrechi, M. S. \& Rius, F. X. (1994). Relationship between geographical origin and chemical composition of wood for oak barrels. American Journal of Enology and Viticulture, Vol. 45, pp. 192-200.

Marín, J.; Zalacain, A.; De Miguel, C.; Alonso, G. L. \& Salinas, M. R. (2005). Stir bar sorptive extraction for the determination of volatile compounds in oak-aged wines. Journal of Chromatography A, Vol.1098, pp. 1-6

Marriott, P. J.; Eyres, G. T. \& Dufour, J. -P. (2009). Emerging Opportunities for Flavor Analysis through Hyphenated Gas Chromatography, Journal of Agricultutal and Food Chemistry, Vol.57, pp. 9962-9971

Martendal, E.; Budziak, D. \& Carasek, E. (2007). Application of fractional factorial experimental and Box-Behnken designs for optimization of single-drop microextraction of 2,4,6-trichloroanisole and 2,4,6-tribromoanisole from wine samples. Journal of Chromatography A, Vol. 1148, pp. 131-136 
Masson, G.; Guichard, E.; Fournier, N. \& Puech, J. L. (1995). Stereoisomers of $\beta$-methyl- $\gamma$ octalactone. 2. Contents in the wood of French (Quercus robur and Quercus petraea) and American (Quercus alba) oaks. American Journal of Enology and Viticulture, Vol. 46, pp. 424- 428.

Masson, G.; Guichard, E.; Fournier, N. \& Puech, J. L. (1997) The $\beta$-methyl- $\gamma$-octalactone stereoisomer contents of European and American oak. Applicable to wines and spirits. Journal des Sciences et Techniques de la Tonnellerie, Vol. 3, pp. 9-15.

Morales, M.L.; Benitez, B. \& Troncoso, A. M. (2004). Accelerated aging of wine vinegars with oak chips: evaluation of wood flavour compounds. Food Chemistry, Vol.88, pp. 305315

Mosedale, J.R. \& Puech, J.-L. (1998) Wood maturation of distelled beverages. Trends in Food Science \& Technology, Vol. 9, pp. 95-101

Natali, N.; Chinnici, F. \& Riponi, C. (2006). Characterization of Volatiles in Extracts from Oak Chips Obtained by Accelerated Solvent Extraction (ASE). Journal of Agricultural Food Chemistry, Vol.54, pp. 8190-8198

Netto, C.C.; Moreira, R.F.A. \& De Maria, C.A.B. (2003). Note: Volatile profile from Caninha aged in oak (Quercus sp) and balsam (Myroxylon, sp) barrels. Food science and Technology International, Vol. 9, pp. 59-64

Nonier, M.F. ;Vivas, N. ; Vivas de Gaulejac, N. ; Absalon, C.; Soulie, Ph \& Fouquet, E. (2006) Pyrolysis-gas chromatography/mass spectrometry of Quercus sp. wood. Application to structural elucidation of macromolecules and aromatic profiles of different species, Journal of Analytical and Applied Pyrolysis, Vol. 75, pp. 181193.

Ochiai. N \& Sasamoto, K. (2011). Selectable one-dimensional or two-dimensional gas chromatography-olfactometry/mass spectrometry with preparative fraction collection for analysis of ultra-trace amounts of odor compounds. Journal of Chromatography A, Vol.1218, pp. 3180-3185

Ortega, C.; Lopez, R.; Cacho, J. \& Ferreira, V. (2001). Fast analysis of important wine volatile compounds: Development and validation of a new method based on gas chromatographic-flame ionization detection analysis of dichloromethane microextracts. Journal of Chromatography, Vol.923, pp. 205-214.

Pawliszyn, J. (1997). Solid Phase Microextraction: Theory and Practice. Wiley-VCH, Inc., New York, USA, 242 pp..

Pérez-Coello, M. S.; Sanz, J. \& Cabezudo, D. (1999) Determination of volatile compounds in hydroalcoholic extracts of French and American oak wood. American Journal of Enology and Viticulture, Vol. 50 pp. 162- 165

Pérez-Coello, M.S.; Sánchez, M. A.; García, E.; González-Viñas, M.A.; Sanz, J. \&. Cabezudo, M.D. (2000). Fermentation of White Wines in the Presence of Wood Chips of American and French Oak. Journal of Agricultural and Food Chemistry, Vol. 48, pp. 885-889

Pérez-Prieto, L.J.; Lopez-Roca, J.M.; Martínez-Cutillas, A.; Pardo-Minguez, F. \& GómezPlaza, E. (2003). Extraction and formation dynamic of oak-related volatile compounds from different volume barrels to wine and their behavior during bottle storage. Journal of Agricultural and Food Chemistry, Vol. 51, pp. 5444-5449. 
Pérez-Prieto, L.J.; López-Roca, J.M.; Martínez-Cutillas, A.; Pardo-Minguez, F. \& GómezPlaza, E. (2002). Maturing wine in oak barrels. Effects of origin, volume, and age of the barrel on the wine volatile composition. Journal of Agricultural and Food Chemistry, Vol. 50, pp. 3272-3276.

Piggott, J.R. ; Conner, J.M. \& Paterson, A. (1995). Flavour development in whisky maturation. in Food Flavors: Generation, Analysis and Process Influence, G. Charalambous (Ed.), pp. $1731-1751$

Plutowska, B \& Wardencki, W. (2008). Application of gas chromatography-olfactometry (GC-O) in analysis and quality assessment of alcoholic beverages - A review, Food Chemistry, Vol.107, pp. 449-463

Pons, A.; Lavigne, V.; Eric, F.; Darriet, P. \& Dubourdieu, D. (2008). Identification of Volatile Compounds Responsible for Prune Aroma in Prematurely Aged Red Wines. Journal of Agricultural Food Chemistry, Vol.56, pp. 5285-5290

Prida, A. \& Puech, J.L. (2006) Influence of Geographical Origin and Botanical Species on the Content of Extractives in American, French, and East European Oak Woods. Journal of Agricultural and Food Chemistry, Vol. 54, pp. 8115-8126

Puech, J.L. (1987). Extraction of phenolic compounds from oak wood in model solutions and evolution of aromatic aldehydes in wine aged in oak barrels. American Journal of Enology and Viticulture, Vol. 38, pp. 236-238

Rocha, S. M.; Coelho, E.; Zrostlíková, J. Delgadillo, I \& Coimbra, M. A. (2007). Comprehensive two-dimensional gas chromatography with time-of-flight mass spectrometry of monoterpenoids as a powerful tool for grape origin traceability. Journal of Chromatography A, Vol.1161, pp. 292-299

Rodríguez-Bencomo, J.J.; Ortega-Heras, M.; Pérez-Magariño, S. \& Gónzalez-Huerta (2009). Volatile compounds of red wines macerated with Spanish, American, and French oak chips. Journal of Agricultural and Food Chemistry, Vol. 57, pp. 6383-6391

Rodríguez-Bencomo, J.J.; Ortega-Heras, M.; Pérez-Magariño, S.; Gónzalez-Huerta, C. \& Gónzalez-Sanjosé, M.L. (2008). Importance of chip selection and elaboration process on the aromatic composition of finished wines. Journal of Agricultural and Food Chemistry, Vol. 56, pp. 5102-5111

Rodríguez-Rodríguez, P. \& Gómez-Plaza, E. (2011). Differences in the Extraction of Volatile Compounds from Oak Chips in Wine and Model Solutions American Journal of Enology and Viticulture, Vol. 62, pp. 127-132

Rojas, F. S.; Ojeda, C. B. \& , Pavón, J. M. C. (2009). A Review of Stir Bar Sorptive Extraction. Chromatographia, Vol. 69, pp. S79-S94

Ryan, D.; Watkins, P.; Smith, J.; Allen, M. \& Marriott, P. (2005). Analysis of methoxypyrazines in wine using headspace solid phase microextraction with isotope dilution and comprehensive two-dimensional gas chromatography. Journal of Separation Science, Vol.28, pp. 1075-1082

Sádecká, J. \& Polonský. J. (2000). Electrophoretic methods in the analysis of beverages. Journal of Chromatography A, Vol. 880, pp.243-279 
Sáenz-Navajas M-P; Campo, E.; Fernández-Zurbano, P.; Valentin, D. \& Ferreira, V. (2010). An assessment of the effects of wine volatiles on the perception of taste and astringency in wine. Food Chemistry, Vol. 121, pp. 1139-1149.

Schmar, H. -G; Ganß, S.; Koschinski, S.; Fischer, U; Riehle, C.; Kinnart, J.; Potouridis, T. \& Kutyrev, M. (2010 a). Pitfalls encountered during quantitative determination of 3alkyl-2-methoxypyrazines in grape must and wine using gas chromatographymass spectrometry with stable isotope dilution analysis. Comprehensive twodimensional gas chromatography-mass spectrometry and on-line liquid chromatography-multidimensional gas chromatography-mass spectrometry as potential loopholes. Journal of Chromatography A, Vol. 217, pp. 6769-6777

Schmarr, H.-G \& Bernhardt, J. (2010). Profiling analysis of volatile compounds from fruits using comprehensivetwo-dimensional gas chromatography and image processing techniques. Journal of Chromatography A, Vol.1217, pp. 565-574

Schmarr, H.-G.; Ganß, S.; Sang, W. \& Potouridis, T. (2007). Analysis of 2aminoacetophenone in wine using a stable isotope dilution assay and multidimensional gas chromatography-mass spectrometry. Journal of Chromatography A, Vol.1150, pp. 78-84

Schmarr, H.-G; Bernhardt, J.; Fischer, U.; Stephan, A.; Müller, P. \& Durner, D. (2010 b). Twodimensional gas chromatographic profiling as a tool for a rapid screening of the changes in volatile composition occurring due to microoxygenation of red wines. Analytica Chimica Acta, Vol.672, pp. 114-123

Sefton, M.; Francis, I.; Williams, P. (1990). Volatile norisoprenoid compounds as constituents of oak woods used in wine and spirit maturation. Journal of Agricultural and Food Chemistry, Vol 38, pp. 2045-2049

Sefton, M.A., Spillman, P.J.; Pocock, K.F.; Francis, I.L. \& Williams, P.J. (1993). The influence of oak origin, seasoning, and other industry practices on the sensory characteristics and composition of oak extracts and barrel-aged white wines. Australian Grapegrower \& Winemaker, Vol. 355, pp. 17-25

Serradilla, J. A. P. \& de Castro, M. D. L. (2011). Microwave-assisted extraction of phenolic compounds from wine lees and spray-drying of the extract. Food Chemistry, Vol.124, pp. 1652-1659

Sillero, I. M.; Herrador, E. A.; Cárdenas, S. \& Valcárcel, M. (2011). Determination of 2,4,6tricholoroanisole in water and wine samples by ionic liquid-based single-drop microextraction and ion mobility spectrometry. Analytica Chimica Acta, Vol.702, pp. 199- 204

Singleton, V.L., \& Draper, D.E. (1961). Wood chips and wine treatment: The nature of aqueous alcohol extracts. American Journal of Enology and Viticulture, Vol.12, pp.152158

Togores, J. H. (2004). Tratado de enologia Tomo 2. Mundiprensa Ed.

Torres, M.P.; Cabrita, M.J.; Gomes da Silva, M. D. R.; Palma, V. \& Costa Freitas, A. Ma . (2011).The Impact of the Malolactic Fermentation in the Volatile Composition of Trincadeira Wine Variety. Journal of Food Biochemistry, Vol. 35, pp. 898-913.

Tredoux, A.; de Villiers, A.; Májek, P.; Lynen, F.; Crouch, A. \& Sandra, P. (2008). Stir Bar Sorptive Extraction Combined with GC-MS Analysis and Chemometric Methods 
for the Classification of South African Wines According to the Volatile Composition, Journal of Agricultural and. Food Chemistry, Vol. 56, pp. 4286-4296

van Jaarsveld, F.P.; Hattingh, S. \& Minnaar, P. (2009). Rapid induction of ageing character in brandy products - Part III. Influence of toasting. South African Journal for Enology $\mathcal{E}$ Viticulture, Vol. 30, pp. 24-37

Vaz-Freire, L. T.; Gomes da Silva, M. D. R. \& Costa Freitas, A. M. (2009). Comprehensive two-dimensional gas chromatography for fingerprint pattern recognition in olive oils produced by two different techniques in Portuguese olive varieties Galega Vulgar, Cobrançosa e Carrasquenha. Analytica Chimica Acta, Vol.633, pp. 263-270

Vichi, S.; Santini, C.; Natali, N.; Riponi, C.; Tamames, E. L. \& Buxaderas, S. (2007). Volatile and semi-volatile components of oak wood chips analysed by Accelerated Solvent Extraction (ASE) coupled to gas chromatography-mass spectrometry (GC-MS). Food Chemistry, Vol.102, pp. 1260-1269

Vivas, N. Glories, Y.; Doneche, B \& Gueho, E. (1991). Observation on the oak wood microflora (Quercus sp) during its natural air drying. Annales des Sciences Naturelles- Botanique et Biologie Vegetale, Vol. 11, pp. 149-153

Waterhouse, A.L., \& Towey, J.P. (1994). Oak lactone isomer ration distinguishes between wine fermented in American and French oak barrels. Journal of Agricultural and Food Chemistry, Vol. 42, pp. 1971-1974

Weldegergis, B. T.; Croucha, A. M.; Górecki, T. \& de Villiers, A. (2011). Solid phase extraction in combination with comprehensive two-dimensional gas chromatography coupled to time-of-flight mass spectrometry for the detailed investigation of volatiles in South African red wines. Analytica Chimica Acta, Vol.701, pp. 98- 111

Yokotsuka, K; Matsunaga, M. \& Singleton, V.L (1994). Comparision of composition of Koshu white wines fermented in oak barrels and plastic tanks. American Journal of Enology and Viticulture, Vol. 45, pp. 11-16

Zhao, Y.P.; Wang, L.; Li, J. M.; Pei G. R. \& Liu, Q. S. (2011) Comparison of Volatile Compounds in Two Brandies Using HS-SPME Coupled with GC-O, GC-MS and Sensory Evaluation- South African Journal of Enology and Viticulture, Vol. 32, pp. 9-20 


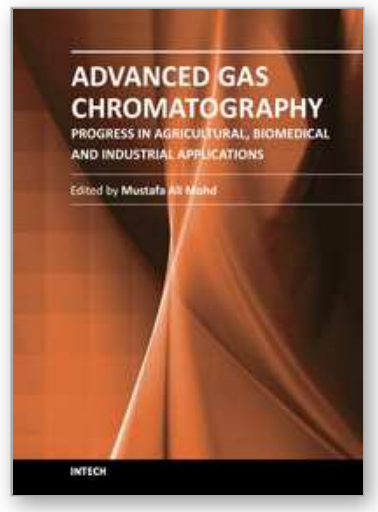

\author{
Advanced Gas Chromatography - Progress in Agricultural, \\ Biomedical and Industrial Applications \\ Edited by Dr. Mustafa Ali Mohd
}

ISBN 978-953-51-0298-4

Hard cover, 460 pages

Publisher InTech

Published online 21, March, 2012

Published in print edition March, 2012

Progress in agricultural, biomedical and industrial applications' is a compilation of recent advances and developments in gas chromatography and its applications. The chapters cover various aspects of applications ranging from basic biological, biomedical applications to industrial applications. Book chapters analyze new developments in chromatographic columns, microextraction techniques, derivatisation techniques and pyrolysis techniques. The book also includes several aspects of basic chromatography techniques and is suitable for both young and advanced chromatographers. It includes some new developments in chromatography such as multidimensional chromatography, inverse chromatography and some discussions on two-dimensional chromatography. The topics covered include analysis of volatiles, toxicants, indoor air, petroleum hydrocarbons, organometallic compounds and natural products. The chapters were written by experts from various fields and clearly assisted by simple diagrams and tables. This book is highly recommended for chemists as well as non-chemists working in gas chromatography.

\title{
How to reference
}

In order to correctly reference this scholarly work, feel free to copy and paste the following:

Maria João B. Cabrita, Raquel Garcia, Nuno Martins, Marco D.R. Gomes da Silva and Ana M. Costa Freitas (2012). Gas Chromatography in the Analysis of Compounds Released from Wood into Wine, Advanced Gas Chromatography - Progress in Agricultural, Biomedical and Industrial Applications, Dr. Mustafa Ali Mohd (Ed.), ISBN: 978-953-51-0298-4, InTech, Available from: http://www.intechopen.com/books/advanced-gaschromatography-progress-in-agricultural-biomedical-and-industrial-applications/gas-chromatography-inanalysis-of-compounds-released-from-wood-into-wine

\section{INTECH}

open science | open minds

\author{
InTech Europe \\ University Campus STeP Ri \\ Slavka Krautzeka 83/A \\ 51000 Rijeka, Croatia \\ Phone: +385 (51) 770447 \\ Fax: +385 (51) 686166 \\ www.intechopen.com
}

\author{
InTech China \\ Unit 405, Office Block, Hotel Equatorial Shanghai \\ No.65, Yan An Road (West), Shanghai, 200040, China \\ 中国上海市延安西路65号上海国际贵都大饭店办公楼405单元 \\ Phone: +86-21-62489820 \\ Fax: $+86-21-62489821$
}


(C) 2012 The Author(s). Licensee IntechOpen. This is an open access article distributed under the terms of the Creative Commons Attribution 3.0 License, which permits unrestricted use, distribution, and reproduction in any medium, provided the original work is properly cited. 